\title{
Exocrine Pancreatic Insufficiency, as Assessed by Fecal Elastase-1 Levels, in Diabetic Patients: An Estimate of Prevalence in Prospective Studies
}

Angelo Andriulli ${ }^{1 *}$, Antonio Massimo Ippolito ${ }^{1}$, Virginia Festa ${ }^{2}$, Maria Rosa Valvano ${ }^{1}$, Antonio Merla ${ }^{1}$, Fabrizio Bossa ${ }^{1}$, Grazia Niro ${ }^{1}$, Grazia Napolitano ${ }^{1}$, Luigi Benini $^{3}$ and Italo Vantini ${ }^{3}$

${ }^{1}$ Divisions of Gastroenterology, "Casa SollievoSofferenza" Hospital, IRCCS, Italy

2"San Filippo Neri" Hospital, Roma, Italy

${ }^{3}$ Chair of Gastroenterology, Universityof Verona, Italy

"Corresponding author: Angelo Andriulli, Division of Gastroenterology, "Casa SollievoSofferenza" Hospital, San Giovanni Rotondo, Italy, Tel: +39 0882 410263; Fax +39 0882 835411; E-mail: antonio.ippolito@me.com

Rec date: Apr 19, 2014, Acc date: May 27, 2014, Pub date: May 30, 2014

Copyright: (C) 2014 Andriulli A, et al. This is an open-access article distributed under the terms of the Creative Commons Attribution License, which permits unrestricted use, distribution, and reproduction in any medium, provided the original author and source are credited.

\begin{abstract} (DM).

Objective: To assess the prevalence of pancreatic exocrine insufficiency (PEI) inpatients with diabetes mellitus

Design: Meta-analysis of prospective, observational studies that used fecal elastase-1 estimation to determine $\mathrm{PEI}$ in patients with DM.

Data extraction: A total of 11 studies out of 1156 retrieved references, published between 2000 and 2013 , fulfilled the inclusion criteria. The primary outcome measure was proportions of patients with DM and PEI.

Results: Of the 2891 patients enrolled, 921 (31.8\%) showed abnormal (i.e, $<200 \mu \mathrm{g} / \mathrm{g}$ ) fecal elastase-1 excretion. Prevalence of PEI varied across studies, with figures ranging from $5 \%$ to $57 \%$. After pooling rates from individual reports, a weighted prevalenceof $31.6 \%$ with $95 \%$ confidence intervals $(\mathrm{CI})$ of $24.8-39.3$ was estimated. Of the 906 patients with abnormal fecal elastase-1, half had severe $(<100 \mu \mathrm{g} / \mathrm{g})$ and half a mild to moderate impairment $(>100$ but $<200 \mu \mathrm{g} / \mathrm{g})$ in elastase-1 excretion. In 921 patients with type-1 DM, the weighted rate of $\mathrm{PEI}$ was $37.7 \%(\mathrm{Cl}$ 27.2-49.5), and 26.2\% (Cl 19.4-34.3) in 1970 type-2 diabetic patients, a difference of $11.5 \%$ ( $p=0.09)$. Of patients with abnormal $(<200 \mu \mathrm{g} / \mathrm{g})$ fecal elastase-1 concentrations, severe $\mathrm{PEI}$ was present in $53.4 \%(\mathrm{Cl} 45.2-61.4)$ of type-1, and in $50.3 \%$ (Cl $40.7-59.9)$ of type-2 diabetic patients.
\end{abstract}

Limitation: Some variables, which may influence fecal elastase-1 excretion, could not be controlled due to missing data.

Conclusions: When explored by fecal elastase-1 testing, one in three patients with DM showed signs of impaired exocrine function. The results suggest that testing for PEI should be part of the diagnostic work-up of patients with DM.

Keywords: Diabetes; Fecal elastase-1; Pancreas; Exocrine insufficiency

\section{Introduction}

Approximately $90 \%$ of the pancreas is made up of exocrine tissue comprising acinar cells which secrete pancreatic enzymes, and ductal cells which secrete bicarbonate rich fluid. About $1 \%$ of the pancreas is endocrine tissue, the remainder being stromal tissue. As long as $20-40 \%$ of the $B$-cell mass is preserved, fasting plasma glucose and insulin levels are often normal. Only when around $80 \%$ of the $B$-cells have been destroyed does fasting hyperglycemia develop [1]. In patients with diabetes mellitus (DM), several reports have documented gross and microscopic alterations of the morphology of acinar cells, some showing pancreatic duct changes recalling a chronic pancreatitis [2-5]. In addition, Pancreatic Exocrine Insufficiency (PEI) is present in a considerable percentage of diabetics [6-9]. As more than $90 \%$ of exocrine function is usually lost before fat malabsorption manifests
[10], it is intriguing to speculate how the damage of the $1 \%$ endocrineportion of the parenchyma, which will manifest itself as DM, may impact on the function of the remaining $90 \%$ exocrine-secreting portion.

Early studies on exocrine pancreatic function in DM were performed by direct pancreatic function tests (i.e., the secretincholecystokinin or the secretin-caerulein test). By this way, PEI was documented in about $50 \%$ of patients with insulin-dependent diabetes, and in $30-50 \%$ of those with non insulin-dependent diabetes [11-13]. Due to the invasive nature of tests that contemplate duodenal intubation and continuous aspiration of duodenal secretion, previous studies were limited due to small number of patients.

Aim of this study was to carry out a systematic review of data that could help assess prevalence of PEI in adults with DM. To overcome methodological pit falls of previous reports which explored pancreatic exocrine function by means of direct tests, we used fecal elastase- 1 estimation, a new indirect test for pancreatic function. The relative 
Citation: Andriulli A, Ippolito AM, Festa V, Valvano MR, Merla A, et al. (2014) Exocrine Pancreatic Insufficiency, as Assessed by Fecal Elastase-1 Levels, in Diabetic Patients: An Estimate of Prevalence in Prospective Studies. J Diabetes Metab 5: 379. doi: $10.4172 / 2155-6156.1000379$

Page 2 of 6

merits and deficiencies of using fecal elastase as a test for pancreatic function are beyond the scope of this study, and have been discussed elsewhere [14-18].

\section{Methods}

Data for this systematic review were collected with an advanced document protocol in accordance with PRISMA guidelines [19] (Appendix 1). All steps in the literature search, study identification, study eligibility, quality assessment, and data extraction were performed independently by two clinical researchers (AI and VF). Disagreements were reconciled through discussion, and consensus was achieved in the selection of articles for analysis.

\section{Study identification}

A comprehensive, computerized literature search was conducted in MEDLINE, EMBASE, the Cochrane Library, and Clinicaltrials.gov. We searched for relevant studies published from inception through September 2013, using the following phrase and Boolean logic algorithm: ("diabetes mellitus"[MeSH Terms] OR ("diabetes"[All Fields] AND "mellitus"[All Fields]) OR "diabetes mellitus"[All Fields]) AND exocrine[All Fields] AND ("pancreas"[MeSH Terms] OR "pancreas"[All Fields] OR "pancreatic"[All Fields]). Additional studies were also searched through cross-referencing bibliography of identified articles. Only articles written in English were included. After examining titles and abstracts, full-text articles of potentially relevant studies were obtained.

\section{Study selection}

Articles were reviewed using the following inclusion criteria: prospective surveys where consecutive adults with type-1 or type- 2 DM were investigated for PEI, which had to be assessed by means of fecal elastase-1 determination. The following exclusion criteria were applied: 1) studies with a retrospective design, 2) DM onset after acute pancreatitis, chronic pancreatitis or cystic fibrosis 3) DM and pancreatic cancer, 4) pancreatic islet transplantation in DM, 5) maturity-onset DM of the young, 6) pediatric patients with DM, 7) evaluation methods for PEI different from fecal elastase-1 estimation, 8) articles concerning overlapping samples and/or duplicate reports from the same investigators.

\section{Methodological quality assessment}

Quality of each study was evaluated by means of the Evidence Evaluation Process elaborated by the 2010 International Consensus on Cardiopulmonary Resuscitation and Emergency Cardiovascular Care Science, for assessing non randomized trials [20], which uses four quality items with a maximum score of 4 points. The quality terms were defined as "good" if they had all of the relevant quality items (score $=4$ ), "fair" if they had some of the items (score=3), and "poor" if they had only a few items (score $=0-2)$.

\section{Data extraction}

For each article we recorded author, year of publication, design, characteristics of the sample, type-1 or type-2 DM classified according to the American Diabetes Association criteria [21], diabetic history (duration, therapy and complications), clinical symptoms related to $\mathrm{DM}$, and fecal elastase-1 determination. According to literature data
[14-18], fecal elastase-1 levels between 100 and $200 \mu \mathrm{g} / \mathrm{g}$ of stools reflect mild to moderate PEI, and those $<100 \mu \mathrm{g} / \mathrm{g}$ severe PEI.

\section{Summary measures (outcomes)}

The main analysis addressed the weighted estimate of prevalence of PEI in the overall population of diabetics enrolled into the selected studies. Secondary outcome was the ascertainment of PEI in patients with type- 1 or type- 2 DM.

\section{Statistical analysis}

Summary outcomes are described as proportions and 95\% Confidence Intervals (CI). We used random effects models to estimate pooled proportions in order to take into account heterogeneity among studies. The degree of heterogeneity was investigated using Cochran's Q-statistic and quantified by I2 (ranges from 0 to 100\%) [22]. In order to explore potential sources of heterogeneity, subgroup analyses were performed based on type- 1 or type- 2 diabetes and on the sample size of the studies ( $\leq$ or $>100$ patients). We also planned to perform sensitivity analyses based on the quality of the trials, and by excluding each individual trial in turnas recommended by the Cochrane Collaboration open learning material for reviewers [23]. All analyses were performed by Comprehensive Meta-Analysis statistical software (version 1.0.25; Biostat, Englewood, NJ).

\section{Results}

\section{Literature flow}

Using keywords and cross-referenced bibliographies, of the 1156 studies identified and examined in depth, 1114 articles were rejected because inclusion criteria were not met; of the 42 prospective surveys selected for potential interest, data of interest for the present investigation were derived from 11 full original articles [15, 24-33]. Reasons for exclusion of studies are shown in Figure 1. The 11 studies included in the quantitative analysis, have been published between 2000 and 2013 and comprised 2891 participants from 8 countries. Methodological and clinical details for each survey are shown in Table 1.

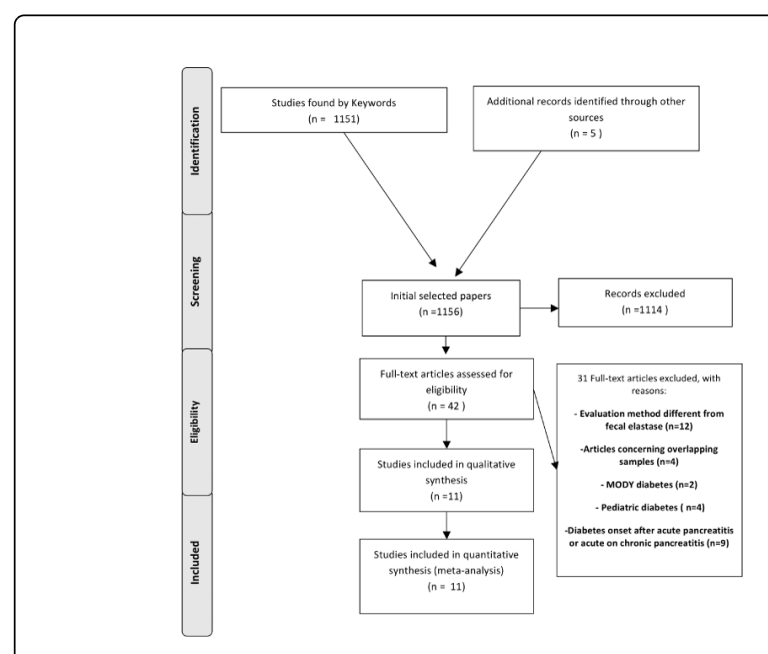

Figure 1: Flow chart of considered studies and finally selected for the meta-analytical evaluation 
Citation: Andriulli A, Ippolito AM, Festa V, Valvano MR, Merla A, et al. (2014) Exocrine Pancreatic Insufficiency, as Assessed by Fecal Elastase-1 Levels, in Diabetic Patients: An Estimate of Prevalence in Prospective Studies. J Diabetes Metab 5: 379. doi: $10.4172 / 2155-6156.1000379$

Page 3 of 6

The average age of participants ranged from 21 to 63 years. Four studies reported fecal elastase-1 measurements in patients with both type-1 or type-2 DM [24-27], four studies exclusively in patients with type-1 $[15,28-30]$, and three studies exclusively in those with type-2 DM [31-33]. All reports used similar criteria to define mild to moderate or severe PEI; a single study did not differentiate the degree of PEI among 33 enrolled patients with type-1 DM [15]. For each considered quality item, the score ranged from 4 to 2 and all, but one, studies were ranked as of high (6 studies) or fair (5 studies) quality (Appendix 2). Overall, of the 2891 surveyed patients, 921 individuals (31.8\%) had type-1 DM, and the remaining 1970 patients (68.2\%) a type-2 DM.

\section{Prevalence of PEI in diabetics}

Table 1 displays the prevalence of PEI, as revealed by fecal elastase- 1 determination, in diabetic patients. Overall, of the 2891 patients evaluated in the 11 prospective observational studies, 921 subjects showed abnormal (i.e., $<200 \mu \mathrm{g} / \mathrm{g}$ ) fecal elastase- 1 concentrations. The prevalence varied across investigated studies, with figures ranging from a low rate of $5 \%$ to the highest value of $57 \%$. After pooling rates from individual reports (Figure 2), a weighted prevalence rate of $31.6 \%$ (CI 24.8-39.3) was estimated. Data across individual investigations resulted heterogeneous $\left(\mathrm{I}^{2}=92 \% ; \mathrm{p}<0.001\right)$. At visual inspection of the Forest plot, the study by Vujasinovic et al. [27], with a prevalence rate as low as $5 \%$, appeared as an outlier. After removing this single study from the analysis, a weighted prevalence of $35.2 \%$ (CI 28.6-42.5) was re-calculated, but the heterogeneity was only marginally reduced $\left(\mathrm{I}^{2}=90 \% ; \mathrm{p}<0.001\right)$.

With the intent to explore further the heterogeneity across studies, we run separate analyses for patients with type-1 or type-2 DM (Table 2). Crude prevalence rates of abnormal fecal elastase-1 concentrations were $40 \%$ (365 of 921) in type-1 DM, and 28\% (556 of 1970) in type-2 diabetics. Here again, figures varied consistently from one report to the other one, ranging between $6 \%$ and $57 \%$ for type- $1 \mathrm{DM}$, and between $5 \%$ and $36 \%$ for type-2 DM. The weighted rates were $37.7 \%$ (CI 27.2-49.5) for type-1 DM, and 26.2\% (CI 19.4-34.3) for type-2 DM, a difference amounting to $11.5 \%(\mathrm{P}=0.09)$. Weighted estimates for both type- 1 and type-2 DM resulted heterogeneous with respective $\mathrm{I}^{2}$ values of $90 \%$ and $91 \%$ (Figure 2).

\begin{tabular}{|c|c|c|c|c|c|c|c|c|c|c|}
\hline \multirow[b]{2}{*}{ Author, year } & \multirow[b]{2}{*}{$\begin{array}{l}\text { Study } \\
\text { design }\end{array}$} & \multicolumn{5}{|l|}{ Total } & \multicolumn{2}{|l|}{ Type 1} & \multicolumn{2}{|l|}{ Type 2} \\
\hline & & No.pts & $\begin{array}{l}\text { Meanage } \\
\text { (yrs) }\end{array}$ & M & $\mathbf{F}$ & $\begin{array}{l}\text { Abnormal } \\
\text { FE-1 No. (\%) }\end{array}$ & No.pts & $\begin{array}{l}\text { Abnormal } \\
\text { FE-1 No. } \\
(\%)\end{array}$ & No.pts & $\begin{array}{l}\text { Abnormal } \\
\text { FE-1 No. } \\
\text { (\%) }\end{array}$ \\
\hline & & $n=2891$ & & $n=1757$ & $n=1134$ & $n=921$ & $\mathrm{n}=921$ & $n=365$ & $n=1970$ & $n=556$ \\
\hline $\begin{array}{l}\text { Hardt } P \text { et al. } \\
2000[24]\end{array}$ & Case-control & 114 & 60 & 67 & 47 & $46(40)$ & 31 & $17(55)$ & 83 & $29(35)$ \\
\hline $\begin{array}{l}\text { Rathmann W. } \\
\text { et al } 2001 \text { [31] }\end{array}$ & Case-control & 544 & 63 & 348 & 196 & $165(30)$ & - & - & 544 & $165(30)$ \\
\hline $\begin{array}{l}\text { Icks } A \text { et al. } \\
2001 \text { [29] }\end{array}$ & Case-control & 112 & 37 & 57 & 55 & $51(46)$ & 112 & $51(46)$ & - & - \\
\hline $\begin{array}{l}\text { Hardt } P \text { et al. } \\
2003 \text { [36] }\end{array}$ & Case series & 1020 & 50 & 687 & 333 & $413(40)$ & 323 & $166(51)$ & 697 & 247 (35) \\
\hline $\begin{array}{l}\text { Nunes AC et } \\
\text { al. 2003 [32] }\end{array}$ & Case-control & 42 & 62 & 18 & 24 & $15(36)$ & - & - & 42 & $15(36)$ \\
\hline $\begin{array}{l}\text { Cavalot F et al. } \\
2004 \text { [30] }\end{array}$ & Case-control & 37 & 34 & 16 & 21 & $21(57)$ & 37 & $21(57)$ & - & - \\
\hline $\begin{array}{l}\text { Yilmaztepe } \\
\text { et al. } 2005[33]\end{array}$ & Case-control & 32 & 47 & 15 & 17 & $10(31)$ & - & - & 32 & $10(31)$ \\
\hline $\begin{array}{l}\text { Hahn J et al. } \\
2008 \text { [15] }\end{array}$ & Case series & 33 & 40 & 17 & 16 & $15(45)$ & 33 & $15(45)$ & - & - \\
\hline $\begin{array}{l}\text { Vesterhus M et } \\
\text { al. } 2008 \text { [28] }\end{array}$ & Case-control & 140 & 21 & 70 & 70 & $26(19)$ & 140 & $26(19)$ & - & - \\
\hline $\begin{array}{l}\text { Larger E et al. } \\
2012 \text { [26] }\end{array}$ & Case series & 667 & 57 & 390 & 277 & $151(23)$ & 195 & $66(34)$ & 472 & 85 (18) \\
\hline $\begin{array}{l}\text { Vujasinovic M } \\
\text { et al. 2013 [27] }\end{array}$ & Case series & 150 & 59 & 72 & 78 & $8(5)$ & 50 & $3(6)$ & 100 & $5(5)$ \\
\hline
\end{tabular}

Table 1: Characteristics of enrolled trials and prevalence of abnormal $(<200 \mu \mathrm{g} / \mathrm{g})$ fecal elastase 1 (FE-1) levels in diabetic patients

The next attempt to check for heterogeneity was to run subgroup analyses of studies sorted out by sample size of enrolled subjects: in the 4 reports with a sample size larger than 100 patients with type-1 DM
$[25,26,28,29]$, the weighted prevalence of PEI was not different $(36.5 \%$, CI 23.8-51.5) as compared to that registered in studies with lower sample size (37.4\%, CI 17.6-62.6) [15,24,27,30]. Prevalence rates of PEI 
Citation: Andriulli A, Ippolito AM, Festa V, Valvano MR, Merla A, et al. (2014) Exocrine Pancreatic Insufficiency, as Assessed by Fecal Elastase-1 Levels, in Diabetic Patients: An Estimate of Prevalence in Prospective Studies. J Diabetes Metab 5: 379. doi: $10.4172 / 2155-6156.1000379$

Page 4 of 6

in patients with type-2 DM were lower in large ( $\geq 100$ patients) studies [25-27,31] as confronted with that reported in low size studies [24,32,33]: $21.5 \%$ (CI 13.8-32.0) vs. $34.4 \%(27.4-42.2)(\mathrm{p}=0.044)$.

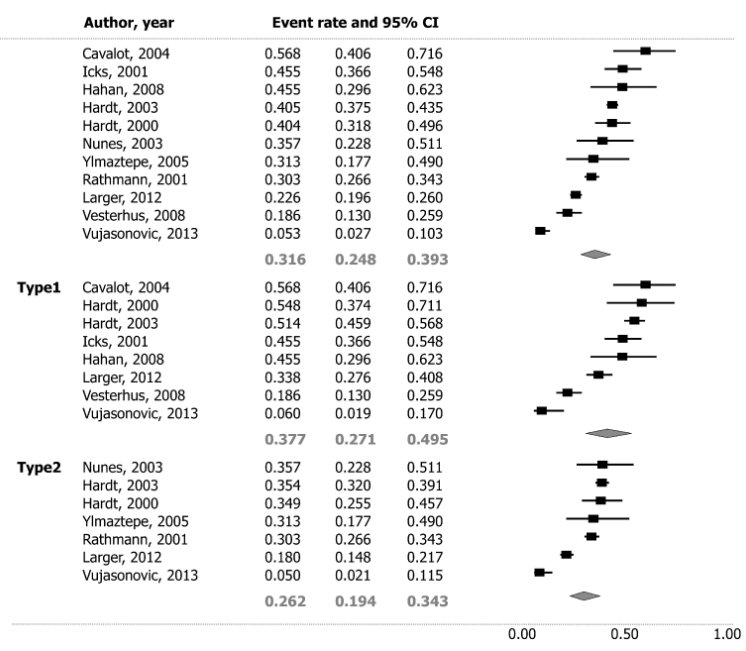

Figure 2: Forest plot of prevalence rate of abnormal $(<200 \mu \mathrm{g} / \mathrm{g})$ fecal elastase- 1 concentrations in the overall population of diabetic patients, as well as in patients sorted by type-1 or type- 2 diabetes mellitus.

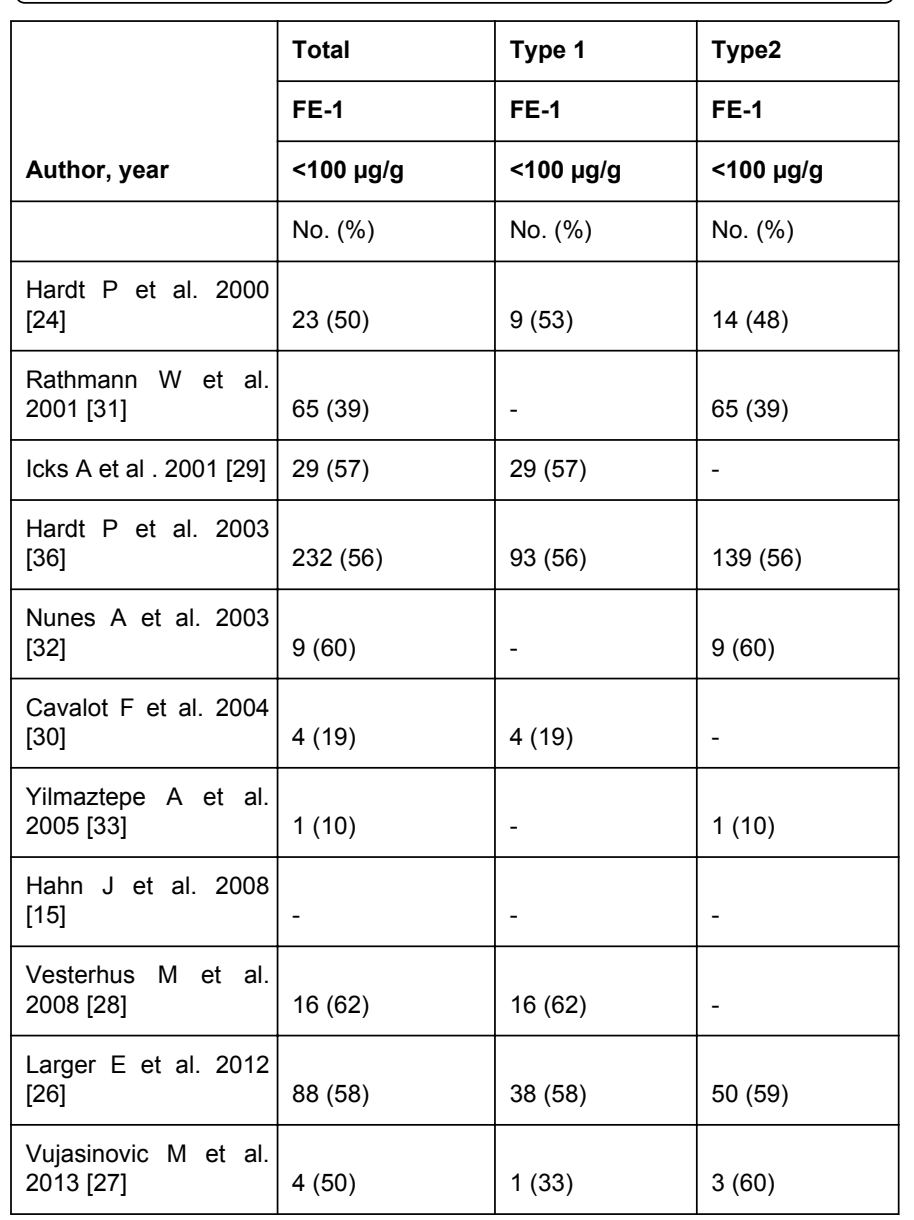

* Percentages refer to the number of patients with exocrine pancreatic insufficiency

Table 2: Severe $(<100 \mu \mathrm{g} / \mathrm{g})$ fecal elastase 1 (FE-1) levels in diabetic patients $^{*}$

\section{Severity of PEI in diabetics}

At exception of a single report [15], all other studies split data for the degree of exocrine impairment. As summarized in Table 2 and Figure 3, of the 906 patients with fecal elastase-1 levels $<200 \mu \mathrm{g} / \mathrm{g}$, half had severe $(<100 \mu \mathrm{g} / \mathrm{g})$ and half a mild to moderate impairment $(>100$ but $<200 \mu \mathrm{g} / \mathrm{g}$ ) in elastase-1 excretion. The weighted estimates for mild/moderate or severe PEI were 50\% (CI 42.3-57.8) and 50\% (42.2-57.7) respectively, with heterogeneous values (I2=69\%). Of the 350 patients with type-1 DM, 160 subjects had moderate and 190 subjects a severe reduction in fecal elastase-1 concentration. The weighted estimates of prevalence rates of mild/moderate or severe PEI in patients with type-1 DM were $46.6 \%$ (CI 38.6-54.8) and $53.4 \%$ (45.2-61.4), respectively $(\mathrm{P}=0.253)$. Among the 556 patients with type-2 DM, mild/moderate and severe PEI was reported in 275 and 281 patients, respectively. After pooling data from 7 studies, weighted estimates of mild/moderate or severe PEI were $49.7 \%$ (CI 40.1-59.3) and $50.3 \%$ (CI 40.7-59.9), respectively $(\mathrm{P}=0.938)$.

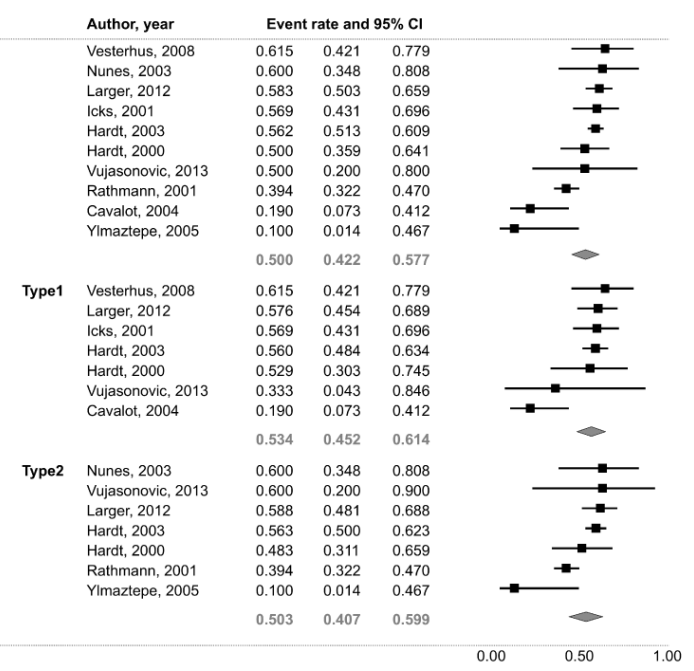

Figure 3: Forest plot of prevalence rate of severe $(<100 \mu \mathrm{g} / \mathrm{g})$ fecal elastase-1 concentrations in the overall population of diabetic patients, as well as in patients sorted by type- 1 or type- 2 diabetes mellitus

\section{Discussion}

This study is the first meta-analysis of the prevalence of PEI, ascertained by means of fecal elastase- 1 excretion, in patients with $\mathrm{DM}$, an issue that has been mentioned for a long time. In the 11 prospective studies selected for the quantitative analysis, the reported prevalence of PEI varied widely from $5 \%$ to $57 \%$. From our metaanalysis it emerged that one in three patients with DM presented with impaired exocrine function when explored by fecal elastase- 1 testing. The weighted prevalence rate of PEI was marginally higher in patients with type-1 DM (37.7\%, CI 27.2-49.5) when confronted with that 
Citation: Andriulli A, Ippolito AM, Festa V, Valvano MR, Merla A, et al. (2014) Exocrine Pancreatic Insufficiency, as Assessed by Fecal Elastase-1 Levels, in Diabetic Patients: An Estimate of Prevalence in Prospective Studies. J Diabetes Metab 5: 379. doi: $10.4172 / 2155-6156.1000379$

Page 5 of 6

registered in those with type-2 DM (26.2\%, CI 19.4-34.3); the $11.5 \%$ difference did not reach the level of significance $(\mathrm{P}=0.09)$. As to the severity of PEI, half of patients with PEI had a severe impairment and the other half mild/moderate impairment, and these figures were independent from the type of DM. Our findings, which originated by studies using fecal elastase-1 excretion as level of PEI, are in keeping with the $30-50 \%$ prevalence figures in type-1 DM and the $15-35 \%$ values in type-2 DM registered in studies using direct tests for exocrine functional evaluation [34].

The vast majority of cases of diabetes fall into two broad etiopathogenic categories: in type-1 DM, the etiopathogenic clue is $\beta$ cell destruction, usually leading to insulin deficiency, whereas in type-2 DM insulin resistance and relative insulin deficiency have been implicated [21]. In the former category, the cause of the exocrine functional impairment is commonly referred to lack of local trophic insulin action which will determine acinar atrophy $[7,8]$. However, this claim does not explain why most patients with type-1 DM manifest no signs of PEI, and why patients with type-2 DM, in whom local deficiency of insulin occurs late when the disease progresses, show signs of PEI. In addition, the assumption that PEI is a diabetesassociated complication mediated by autonomic neuropathy which might lead to impaired entero-pancreatic reflexes [9] or by angiopathy which would lead to arterial lesion and pancreatic fibrosis [10-12] has few supporting evidences. An alternative hypothesis argues that chronic inflammation, of likely viral or autoimmune nature, might damage simultaneously the exocrine and the endocrine portion of the parenchyma [13,35]. To this respect we would recall that gross alterations of pancreatic morphology are increasingly recognized at imaging studies in patients with either type-1 or type-2 DM [2-5]. One might hypothesize that any process that diffusely injuries the pancreas will impair simultaneously either the exocrine or the endocrine portion of the organ: due to the exiguity of endocrine cells (about $1 \%$ of the total glandular parenchyma), signs of impaired glucose homeostasis will dominate the clinical scenario at the initial steps of the pancreatic inflammation. At this time, owing to the overwhelming exocrine secretory capability, evidences of failing exocrine secretion might go clinically unrecognized and become manifest only by appropriate testing.

As to the clinical implication of PEI in diabetics, it should be recalled that PEI was severe in half of patients with type- 1 or type- 2 DM with abnormal fecal elastase-1 concentrations. Of relevance, Hardt et al. [36] showed that about $60 \%$ of patients with low fecal elastase- 1 concentrations have pathological fat excretion of $>7 \mathrm{~g}$ /day. Moreover, patients with DM frequently suffer from a wide range of abdominal symptoms which markedly contribute to impairment of quality of life [37]. At least some of these symptoms, such as pain and diarrhea, may be attributable in part to (mild to moderate) PEI and might respond to pancreatic enzyme treatment [38]. Enzyme replacement therapy might have an impact on glucose metabolism, as it can reduce insulin requirement and improve control of glucose metabolism, but evidences are contradictory [39-41]. Thus, pancreatic tests should be part of the diagnostic work-up in patients with such symptoms who do not respond to simple therapeutic measures.

There was a very high heterogeneity in the prevalence of PEI across the surveyed studies, so that it seems plausible they were not conducted in similar populations. Indeed, a suspicion of a selection bias may be raised if the enrolled patients were not truly consecutive, and it could be argued that patients enrolled into the selected studies were the ones for whom their physicians had high index of clinical suspicion for PEI and for this reason eventually tested for fecal elastase-1 excretion. We acknowledge this as a major limitation of the present study. However, determinants of PEI in patients with DM could not be explored in the present investigation, as pertinent data were irretrievable by most of the studies. Therefore, the relevant clinical question about likely causes for the dispersion in prevalence estimates in the included studies remains unaddressed. Even after running several sub-analyses, heterogeneity across the studies could not be elucidated and we could only ascertain that prevalence rates of DM were marginally higher in type-1 than in type-2 DM.

In conclusion, one in three patients with DM presented with impaired exocrine function when explored by fecal elastase-1 testing. The prevalence of PEI is slightly higher among patients with type 1 DM. Of all patients with DM and PEI, half had severe PEI, as identified by fecal elastase- 1 concentrations $<100 \mu \mathrm{g} / \mathrm{g}$ stool. We would recommend to screen patients with DM and abdominal complaints for PEI: patients showing fecal elastase- $1<100 \mu \mathrm{g} / \mathrm{g}$ should be treated with pancreatic enzymes in adequate daily doses administered at main meals.

\section{References}

1. Vinik AI (1988) Insulin secretion in chronic pancreatitis; in Tiengo A, Alberti KGMM, Del Prato S, Vranic M (ed): Diabetes secondary to pancreopathy. Amsterdam. ExcerptaMedica: 33-50.

2. Nakanishi K, Kobayashi T, Miyashita H, Okubo M, Sugimoto T, et al. (1994) Exocrine pancreatic ductograms in insulin-dependent diabetes mellitus. Am J Gastroenterol 89: 762-766.

3. Hardt PD, Killinger A, Nalop J, Schnell-Kretschmer H, Zekorn T, et al. (2002) Chronic pancreatitis and diabetes mellitus. A retrospective analysis of 156 ERCP investigations in patients with insulin-dependent and non-insulin-dependent diabetes mellitus. Pancreatology 2: 30-33.

4. Silva ME, Vezozzo DP, Ursich MJ, Rocha DM, Cerri GG, et al. (1993) Ultrasonographic abnormalities of the pancreas in IDDM and NIDDM patients. Diabetes Care 16: 1296-1297.

5. Bilgin M, Balci NC, Momtahen AJ, Bilgin Y, Klör HU, et al. (2009) MRI and MRCP findings of the pancreas in patients with diabetes mellitus: compared analysis with pancreatic exocrine function determined by fecalelastase 1. J ClinGastroenterol 43: 165-170.

6. Chey WY, Shay H, Shuman CR (1963) External Pancreatic Secretion In Diabetes Mellitus. Ann Intern Med 59: 812-821.

7. Vacca JB, Henke WJ, Knight WA Jr (1964) The Exocrine Pancreas in Diabetes Mellitus. Ann Intern Med 61: 242-247.

8. Harano Y, Kim CI, Kang M, Shichiri M, Shimizu Y, et al. (1978) External pancreatic dysfunction associated with diabetes mellitus. J Lab Clin Med 91: 780-790.

9. Frier BM, Saunders JH, Wormsley KG, Bouchier IA (1976) Exocrine pancreatic function in juvenile-onset diabetes mellitus. Gut 17: 685-691.

10. DiMagno EP, Go VL, Summerskill WH (1973) Relations between pancreatic enzyme ouputs and malabsorption in severe pancreatic insufficiency. N Engl J Med 288: 813-815.

11. Lankisch PG, Manthey G, Otto J, Koop H, Talaulicar M, et al. (1982) Exocrine pancreatic function in insulin-dependent diabetes mellitus. Digestion 25: 211-216.

12. el Newihi H, Dooley CP, Saad C, Staples J, Zeidler A, et al. (1988) Impaired exocrine pancreatic function in diabetics with diarrhea and peripheral neuropathy. Dig Dis Sci 33: 705-710.

13. Gröger G, Layer P (1995) Exocrine pancreatic function in diabetes mellitus. Eur J GastroenterolHepatol 7: 740-746.

14. Löser C, Möllgaard A, Fölsch UR (1996) Faecal elastase 1: a novel, highly sensitive, and specific tubeless pancreatic function test. Gut 39: 580-586. 
Citation: Andriulli A, Ippolito AM, Festa V, Valvano MR, Merla A, et al. (2014) Exocrine Pancreatic Insufficiency, as Assessed by Fecal Elastase-1 Levels, in Diabetic Patients: An Estimate of Prevalence in Prospective Studies. J Diabetes Metab 5: 379. doi: $10.4172 / 2155-6156.1000379$

Page 6 of 6

15. Hahn JU, Kerner W, Maisonneuve P, Lowenfels AB, Lankisch PG (2008) Low fecalelastase 1 levels do not indicate exocrine pancreatic insufficiency in type-1 diabetes mellitus. Pancreas 36: 274-278.

16. Keller J, Aghdassi AA, Lerch MM, Mayerle JV, Layer P (2009) Tests of pancreatic exocrine function - clinical significance in pancreatic and non-pancreatic disorders. Best Pract Res ClinGastroenterol 23: 425-439.

17. Nandhakumar N, Green MR (2010) Interpretations: How to use faecal elastase testing. Arch Dis Child EducPract Ed 95: 119-123.

18. Benini L, Amodio A, Campagnola P, Agugiaro F, Cristofori C, et al. (2013) Fecal elastase-1 is useful in the detection of steatorrhea in patients with pancreatic diseases but not after pancreatic resection. Pancreatology 13: 38-42.

19. Moher D, Liberati A, Tetzlaff J, Altman DG; PRISMA Group (2009) Preferred reporting items for systematic reviews and meta-analyses: the PRISMA statement. Ann Intern Med 151: 264-269.

20. Morley PT, Atkins DL, Billi JE, Bossaert L, Callaway CW, et al. (2010) Part 3: Evidence evaluation process: 2010 International Consensus on Cardiopulmonary Resuscitation and Emergency Cardiovascular Care Science With Treatment Recommendations. Circulation 122: S283-S290.

21. American Diabetes Association (2011) Diagnosis and classification of diabetes mellitus. Diabetes Care 34: S62-S69.

22. Higgins JP, Thompson SG (2002) Quantifying heterogeneity in a metaanalysis. Stat Med 21: 1539-1558.

23. Alderson P, Green S (2002) Cochrane Collaboration open learning material for reviewers. Version 1.1, Nov 2002, The Cochrane Collaboration ${ }^{\circledast}$.

24. Hardt PD, Krauss A, Bretz L, Porsch-Ozcürümez M, Schnell-Kretschmer $\mathrm{H}$, et al. (2000) Pancreatic exocrine function in patients with type 1 and type 2 diabetes mellitus. ActaDiabetol 37: 105-110.

25. Hardt PD, Hauenschild A, Nalop J, Marzeion AM, Jaeger C, et al. (2003) High prevalence of exocrine pancreatic insufficiency in diabetes mellitus. A multicenter study screening fecalelastase 1 concentrations in 1,021 diabetic patients. Pancreatology 3: 395-402.

26. Larger E, Philippe MF, Barbot-Trystram L, Radu A, Rotariu M, et al (2012) Pancreatic exocrine function in patients with diabetes. Diabet Med 29: 1047-1054.

27. Vujasinovic M, Zaletel J, Tepes B, Popic B, Makuc J, et al. (2013) Low prevalence of exocrine pancreatic insufficiency in patients with diabetes mellitus. Pancreatology 13: 343-346.

28. Vesterhus M, Raeder H, Johansson S, Molven A, Njølstad PR (2008) Pancreatic exocrine dysfunction in maturity-onset diabetes of the young type 3. Diabetes Care 31: 306-310.

29. Icks A, Haastert B, Giani G, Rathmann W (2001) Low fecal elastase-1 in type I diabetes mellitus. Z Gastroenterol 39: 823-830.
30. Cavalot F, Bonomo K, Perna P, Gaia E, Trovati M (2004) Pancreatic elastase- in stools, a marker of exocrine pancreas function, correlates with both residual $B$-cell secretion and metabolic control in type 1 diabetic subjects: response to Mueller et al. Diabetes Care 28: 2810-2811.

31. Rathmann W, Haastert B, Icks A, Giani G, Hennings S, et al. (2001) Low faecal elastase 1 concentrations in type 2 diabetes mellitus. Scand J Gastroenterol 36: 1056-1061

32. Nunes AC, Pontes JM, Rosa A, Gomes L, Carvalheiro M, et al. (2003) Screening for pancreatic exocrine insufficiency in patients with diabetes mellitus. Am J Gastroenterol 98: 2672-2675.

33. Yilmaztepe A, Ulukaya E, Ersoy C, Yilmaz M, Tokullugil HA (2005) Investigation of fecal pancreatic elastase-1 levels in type 2 diabetic patients. Turk J Gastroenterol 16: 75-80.

34. Hardt PD, Brendel MD, Kloer HU, Bretzel RG (2008) Is pancreatic diabetes (type $3 \mathrm{c}$ diabetes) underdiagnosed and misdiagnosed? Diabetes Care 31 Suppl 2: S165-169.

35. Nakanishi K, Kobayashi T, Miyashita H, Okubo M, Sugimoto T, et al. (1993) Relationships among residual beta cells, exocrine pancreas, and islet cell antibodies in insulin-dependent diabetes mellitus. Metabolism 42: 196-203.

36. Hardt PD, Hauenschild A, Jaeger C, Teichmann J, Bretzel RG, et al (2003) High prevalence of steatorrhea in 101 diabetic patients likely to suffer from exocrine pancreatic insufficiency according to low fecalelastase 1 concentrations. A prospective multicenter study. Dig Dis Sci 48: 1688-1692.

37. Talley NJ, Young L, Bytzer P, Hammer J, Leemon M, et al. (2001) Impact of chronic gastrointestinal symptoms in diabetes mellitus on healthrelated quality of life. Am J Gastroenterol 96: 71-76

38. Ewald N, Bretzel RG, Fantus IG, Hollenhorst M, Kloer HU, et al. (2007) Pancreatic therapy in patients with insulin-treated diabetes mellitus ad exocrine pancreatic insufficiency according to low fecalelastase 1 concentrations. Results of a prospective multi-centre trial. Diabetes Metab Res Rev 23: 386-389.

39. Glasbrenner B, Malfertheiner P, Kerner W, Scherbaum WA, Ditschuneit $\mathrm{H}$ (1990) [Effect of pancreatin on diabetes mellitus in chronic pancreatitis]. Z Gastroenterol 28: 275-279.

40. Mohan V, Poongothai S, Pitchumoni CS (1998) Oral pancreatic enzyme therapy in the control of diabetes mellitus in tropical calculous pancreatitis. Int J Pancreatol 24: 19-22.

41. O'Keefe SJ, Cariem AK, Levy M (2001) The exacerbation of pancreatic endocrine dysfunction by potent pancreatic exocrine supplements in patients with chronic pancreatitis. J ClinGastroenterol 32: 319-323. 